\title{
Intriguing Results Regarding the Prevalence and Distribution of Hpv Types in Women with Cervical Cancer in a Romanian Population
}

\author{
Mihai Emil Căpîlna and Mihaela-Alexandra Budianu \\ First Obstetrics and Gynaecology Clinic, University of Medicine and Pharmacy, Romania
}

Submission: March 29, 2017; Published: April 17, 2017

*Corresponding author: Mihai Emil Capîlna, First Obstetrics and Gynaecology Clinic, University of Medicine and Pharmacy, Str Koteles Samuel 16, 540057, Târgu Mureș, Romania, Tel: 0040744271539; Email: mcapilna@gmail.com

\section{Introduction}

Cancer of the uterine cervix is the 5 th most deadly type of female cancer [1]. It is clearly demonstrated that HPV infection is the necessary, but not the sufficient cause of most cervical cancers [2]. The association between cancer of the uterine cervix and HPV is unique because no other human cancer is dependent on a single infectious factor for its development [3]. Worldwide, HPV types 16 and 18 accounts for approximately $70 \%$ of cervical cancer cases with other high-risk types, such as HPV-45, HPV-31, HPV-33, and HPV-52, being responsible for the remaining cases $[4,5]$.

The incidence is highest in developing countries. Little is known about viral and epidemiologic factors in Romania, a country with a high cervical cancer incidence. Few studies have been published [6-9], and they provide little evidence, due to the small sample size and their focus on cytologic abnormalities and pre-invasive cervical lesions, but not in invasive cervical cancer. Thus, the present study is aimed at providing baseline information about HPV prevalence and type distribution in a Romanian population with cervical cancer.

\section{Methods}

\section{Study population and clinical specimens}

The samples included in this study comprised 80 histologically confirmed invasive cervical cancer fresh specimens of previously non-irradiated Romanian women. These samples were collected at the First Obstetrics and Gynaecology Clinic of Târgu Mureș, a tertiary university hospital, between September 2015 and October 2016. The Ethics Committee of the hospital approved the study protocol and the University of Medicine and Pharmacy of Târgu Mureș supported the study by a research grant. Sampling tubes PreservCytTM and AmpliLute Liquid Media Extraction Kit are indispensable parts of the test. All specimens were collected by cervical brush and stored at $+4{ }^{\circ} \mathrm{C}$ until analysed.

\section{HPV genotyping}

Detection consisted in genomic DNA extraction from cervical epithelial cells, PCR amplification of target DNA, hybridization of PCR products with oligonucleotide probes on solid strips and colorimetric identification of hybridization products, according to the manufacturer's guidelines (Roche Molecular). The Master Mix reagent contains a pool of HPV biotinilated primers for the amplification of DNA from 37 HPV genotypes (including 13 high risk genotypes: $16,18,31,33,35,39,45,51,52,56,58,59$ and 68 ) and the human $\beta$-globin gene as a control for cell adequacy, nucleic acid extraction, and PCR efficiency. The PCR denaturated amplicons were then hybridized and detected using the recommended LA protocol. The LA HPV genotyping strips were manually interpreted using the HPV reference guide provided.

\section{Data analysis}

All data of the HPV genotype-specific prevalence was analyzed, calculated, and presented as percentage. A chi square test and a logistic regression were performed to try to find a correlation between HPV type, stage of disease or histologic type. Statistical analyses for $\mathrm{P}$ values were performed using $2-x-2$ contingency tables, with two-tailed $P$ values calculated by using the Fisher exact test. All $p$ values of $<0.05$ were considered statistically significant.

\section{Results}

\section{General characteristics}

The patients' mean age at the time of diagnosis was 49.48 years (between 28 and 68 years old). The majority of histological diagnoses were squamous cell carcinoma (75 out of 80 patients, $93.75 \%)$, with 4 adenocarcinomas (5\%) and 1 neuroendocrine carcinoma. Forty-one patients $(51.25 \%)$ were in stage I (Ia1Ib2), 24 (30\%) in stage II, $14(17.5 \%)$ in stage III and $1(1.25 \%)$ was staged IVa. 


\section{HPV prevalence and type distribution}

Of the 80 samples analyzed, 10 cases $(12.5 \%)$ were negative for HPV-DNA. HPV-DNA prevalence was $87.5 \%$. Most of HPV-DNA positive cervical cancer patients harboured single infections (87.14\%); 7 patients had 2 HPV types (10\%); and in 2 patients, 3 different HPV types were discovered (2.86\%). HPV16 was the most detected type, with $72.5 \%$ relative contribution as single (58 patients) or multiple infection ( 2 cases of double infection and two patients harbouring 3 different HPV types). Other 2 HPV double infection harboured HPV 31 associated with HPV 39 and73. Interestingly, HPV18 was identified only in one biopsy (1.3\%). More high risk HPV types as single infection were found in 2 cases- $2.7 \%$ (HPV 31, 33, 39, 45, 53, 58, 62, 68); other single high risk HPV types were detected in only one woman $-1.3 \%$ ( 56 , $73,82,84$ ). One low risk HPV (type 6) were identified.

It was not found any statistical correlation between the HPV genotype, patients'age, histology of the tumour or stage of disease.

\section{Discussion}

The present study has shown the prevalence of HPV genotypes in a Romanian population with invasive cervical cancer, based on PCR. Our results are intriguing, with a high prevalence of HPV $16(72.5 \%)$ and 10 other high risk HPV type, with a low prevalence (1.3-2.7\%) for each one. HPV 18 was detected in only one patient, despite the presence of 4 adenocarcinoma and one neuroendocrine carcinoma histologies. This high variety of HPV types among Romanian population is quite specific, compared to other recently published data.

Multiple infection was detected in $12.85 \%$ of women in our study, which is extremely high compared with $1.2 \%$ as described in a worldwide study by Munoz [10]. In other studies, multiple infections were reported in $1.7-52.2 \%$ of the cases [11-15]. Yet, in areas with a high overall prevalence of HPV in the normal population, the percentage of multiple infections in the same group seems to be higher [16].

The HPV prevalence in cervical cancer patients differs substantially in other studies performed in different world regions. Regarding other European countries, a pooled analysis study performed in Italy [17] included 574 invasive cervical cancers from 3 different major studies performed in Rome, Milano and Central and Southern Italy comprising the whole genetic pool of the country. HPV 16 genotype was the most detected type, in single $(69,3 \%)$ and in co infections with other genotypes $(58,3 \%)$, in all squamous cell carcinoma and adenocarcinomas. Whereas in the cited study HPV 18 type was the second most common genotype linked with invasive cervical carcinoma $(23,3 \%)$, we can observe that HPV 18 positive infections $(2,13 \%)$ are still in low numbers in the Romanian population. This trend is confirmed also with other HPV high risk types: 45, 31, 58, 33.

In studies performed in Portugal [14] and Croatia [11], HPV prevalence was $97.9 \%, 92.59 \%$ respectively. In another research performed in Northern Ireland [18], HPV was isolated in 92.2\% of squamous cell carcinomas and $64.3 \%$ of adenocarcinoma patients, respectively. Most of squamous cell carcinomas histologies (81.3\%) had only one HPV type detected.

In women from Israel with cervical cancer [19], HPV was positive in $96.5 \%$, and high risk HPV types were detected in 93\%. The most common HPV types was 16 (57.4\%), followed by type 45 (9.6\%), and type 18(7.8\%). Multiple HPV types were seen in $0.9 \%$ of patients.

The HPV prevalence in cervical cancer patients ranged from $84.5 \%$ to $97 \%$ in researches performed in different world regions [20-26], but the prevalence of different HPV types were extremely different between countries. In all studies, HPV 16 was the most prevalent type (36,8-76.7\%), followed by HPV18 (8.5$35.4 \%)$, HPV35 (8.7\%), HPV45 (6.8-17.2\%), HPV33 (3.4-4.0\%) and HPV52 (2.2-10.3\%). The prevalence of HPV 16 is higher in Europe, South America and China compared to other Asian countries; by contrary, HPV 18, 45 and 52 is more frequent in South East Asia compared to the rest of the world.

A very interesting result derived from this study: $12,5 \%$ (10 patients) of the study population where diagnosed with invasive cervical carcinoma with a negative HPV genotyping result. In a study performed on data from 17 European countries, comprising 3162 cases, Tjalma et al. [27] concluded also that $8.2 \%$ of invasive cervical carcinoma where HPV negative.

Interestingly, similar to our research, single low risk HPV infection was also found in some studies $[19,21]$.

\section{Conclusion}

Because of substantial geographical variation in the HPV genotype distribution, data regarding HPV type-specific prevalence for a particular country are mandatory for providing baseline information to estimate effectiveness of currently implemented cervical cancer prevention strategies including HPV-DNA testing-based screening and HPV vaccination. This study provides important baseline data for improving the acceptance of HPV vaccination in Romania.

\section{Acknowledgement}

This study was supported by a research grant offered by the University of Medicine and Pharmacy, Târgu Mureș, Romania.

\section{References}

1. World Health Organization (2006) Fact Sheet No. 297: Cancer.

2. Ho GY, Bierman R, Beardsley L, Chang CJ, Burk RD (1998) Natural history of cervicovaginal papilloma virus infection in young women. $\mathrm{N}$ Engl J Med 338(7): 423-428.

3. Wentzensen N, Arbyn M, Berkhof J, Bower M, Canfell K, et al. (2016) Eurogin 2016 Roadmap: How HPV knowledge is changing screening practice. Int J Cancer 140(10): 2192-2200.

4. Castellsagué X, Díaz M, de Sanjosé S, Muñoz N, Herrero R, et al. (2006) Worldwide human papillomavirus etiology of cervical adenocarcinoma and its cofactors: Implications for screening and prevention. J Natl Cancer Inst 98(5): 303-315. 
5. Muñoz N, Bosch FX, Castellsagué X, Díaz M, de Sanjose S, et al. (2004) Against which human papilloma virus types shall we vaccinate and screen? The international perspective. Int J Cancer 111: 278-285.

6. Ursu RG, Onofriescu M, Nemescu D, Iancu LS (2011) HPV prevalence and type distribution in women with or without cervical lesions in the Northeast region of Romania. Virol J 8: 558.

7. Feticu L, Bocşan IS, Bondor CI, Boboş C (2012) Geographical distribution of human papillomavirus and their correlation with cytologic abnormalities in cervical lesions and with the age in a female population from Transylvania. Rev Med Chir Soc Med Nat Iasi 116(1): 291-298.

8. Melinte-Popescu A, Costăchescu G (2012) Human papilloma virus infection and cervical dysplasia. Rev Med Chir Soc Med Nat Iasi 116(3): 853-857.

9. Voidăzan S, Morariu SH, Căpîlna M, Mărginean C, Dobreanu M (2015) The prevalence and distribution of high risk Human Papillomavirus genotypes in patients with dysplastic lesions: a population study. Acta Medica Marisiensis 61(4): 314-319.

10. Munoz N (2000) Human papillomavirus and cancer: the epidemiological evidence. J Clin Virol 19(1-2): 1-5.

11. Hadzisejdić I, Simat M, Bosak A, Krasević M, Grahovac B (2016) Prevalence of human papillomavirus genotypes in cervical cancer and precursor lesions. Coll Antropol 30(4): 879-883.

12. Ennaifer E, Salhi F, Laassili T, Fehri E, Ben Alaya N, et al. Type-specific Human Papillomavirus distribution in invasive squamous cervical carcinomas in Tunisia and vaccine impact. Asian Pac J Cancer Prev 16(15): 6769-6772.

13. Denny L, Adewole I, Anorlu R, Dreyer G, Moodley M, et al. (2014) Human papillomavirus prevalence and type distribution in invasive cervical cancer in sub-Saharan Africa. Int J Cancer 134(6): 1389-1398.

14. Pista A, de Oliveira CF, Lopes C, Cunha MJ, CLEOPATRE Portugal Study Group (2013) Human papillomavirus type distribution in cervical intraepithelial neoplasia grade 2/3 and cervical cancer in Portugal: a CLEOPATRE II Study. Int J Gynecol Cancer 23(3): 500-506.

15. de Boer MA, Vet JN, Aziz MF, Cornain S, Purwoto G, et al. (2006) Human papillomavirus type 18 and other risk factors for cervical cancer in Jakarta, Indonesia. Int J Gynecol Cancer 16(5): 1809-1814.

16. Pham TH, Nguyen TH, Herrero R, Vaccarella S, Smith JS, et al. (2003) Human papillomavirus infection among women in South and North Vietnam. Int J Cancer 104: 213-220.
17. Rossi GP, Sideri M, Carozzi FM (2012) HPV Prevalence Italian Working Group. Infect Agent Cancer 7(1): 26.

18. Anderson LA, O'Rorke MA, Wilson R, Jamison J, Gavin AT, et al. (2016) HPV prevalence and type-distribution in cervical cancer and premalignant lesions of the cervix: A population-based study from Northern Ireland. J Med Virol 88(7): 1262-1270.

19. Siegler E, Karin Sharir, Ofer Lavie, Pninit Saked-Misan, Lena Machulk, et al. (2016) The prevalence of HPV types in women with CIN 2-3 or cervical cancer in Haifa District, Israel. Minerva Ginecol.

20. Ogembo RK, Gona PN, Seymour AJ, Park HS, Bain PA, et al. (2015) Prevalence of human papillomavirus genotypes among African women with normal cervical cytology and neoplasia: a systematic review and meta-analysis. PLoS One 10(4): e0122488.

21. Ciapponi A, Bardach A, Glujovsky D, Gibbons L, Picconi MA (2011) Type-specific HPV prevalence in cervical cancer and high-grade lesions in Latin America and the Caribbean: systematic review and metaanalysis. PLoS One 6(10): e25493.

22. Chen W, Zhang X, Molijn A, Jenkins D, Shi JF, et al. (2009) Human papillomavirus type-distribution in cervical cancer in China: the importance of HPV 16 and 18. Cancer Causes Control 20(9): 17051713.

23. Quek SC, Lim BK, Domingo E, Soon R, Park JS, et al. (2013) Human papillomavirus type distribution in invasive cervical cancer and highgrade cervical intraepithelial neoplasia across 5 countries in Asia. Int J Gynecol Cancer 23(1): 148-156

24. Berois N, De Cremoux P, Mazal D, Sica A, Cedeira M, et al. (2013) Prevalence and distribution of high-risk human papillomavirus genotypes in invasive carcinoma of the uterine cervix in Uruguay. Int J Gynecol Cancer 23(3): 527-532.

25. Kietpeerakool C, Kleebkaow P, Srisomboon J (2015) Human Papillomavirus Genotype Distribution among Thai Women with HighGrade Cervical Intraepithelial Lesions and Invasive Cervical Cancer: a Literature Review. Asian Pac J Cancer Prev 16(13): 5153-5138.

26. Matsumoto K, Yoshikawa HJ (2013) Human papillomavirus infection and the risk of cervical cancer in Japan. Obstet Gynaecol Res 39(1): 7-17.

27. Tjalma WA, Fiander A, Reich O, Powell N, Nowakowski AM, et al. (2013) Differences in human papillomavirus type distribution in high-grade cervical intraepithelial neoplasia and invasive cervical cancer in Europe. Int J Cancer 132(4): 854-867.

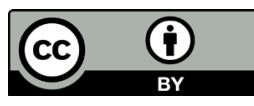

This work is licensed under Creative Commons Attribution 4.0 Licens DOI: $10.19080 /$ JGWH.2017.04.555629

\section{Your next submission with Juniper Publishers} will reach you the below assets

- Quality Editorial service

- Swift Peer Review

- Reprints availability

- E-prints Service

- Manuscript Podcast for convenient understanding

- Global attainment for your research

- Manuscript accessibility in different formats

( Pdf, E-pub, Full Text, Audio)

- Unceasing customer service

Track the below URL for one-step submission https://juniperpublishers.com/online-submission.php 